\title{
Methodology for the Impact Assessment of the Digital Economy on Agriculture Development
}

\author{
Andrii Sakhno, Iryna Salkova, Antonina Broyaka, Nataliia Priamukhina
}

\begin{abstract}
The impact of the digital economy on the development of the agricultural sector was investigated, using the method of analyzing the functioning environment. It was revealed that the current state of the agricultural sector in Ukraine does not significantly depend on the influence and provision of the digital economy. It is proposed to carry out the development of the agro-industrial complex based on priorities for achieving the technical efficiency of economic activities related to the manufacture of computers, electronic and optical products. An assessment of the development of the digital economy in the context of the state of the types of economic activity in agriculture the features of the backlog were revealed and the prospects for the development of agricultural activities through a fundamental reorganization of the economy by developing the manufacture of computer, electronic and optical production were evaluated. The need of the agro-industrial complex of Ukraine for modern information developments that will increase the volume of sales and reduce production and personnel costs is substantiated. Research indicate the necessity for further adjustments to the line of technical efficiency by the method of analyzing the functioning environment in order to develop digital technologies in agriculture, forestry and fisheries.
\end{abstract}

Keywords : agriculture, digital economy, economic activity efficiency, personnel costs, sales volume, value added,.

\section{INTRODUCTION}

The issues of economic development and the impact of digitization, digitalization and globalization processes on it are now more acute in Ukraine than ever. A country cannot stay isolated, and the development of its digitalization affects both politics and the economy. Electronics, programming, communications and robotics complement each other and form the fifth technological structure, laid down by the innovations of the 1970s, which have become an integral part of our lives today. At present, the sixth technological structure is underway - the era of digitalization and nanotechnology, which reduce energy and material consumption of production, open up new possibilities for managing the properties of materials and organisms.

Unfortunately, in the 1990s, in times of hyperinflation, instability and chaos, Ukraine missed the heyday of the fifth technological structure. At that time Ukrainians could apply

Revised Version Manuscript Received on October 15, 2019.

Andrii Sakhno, Dr. Sc. (Economics), Professor, Head of the Department of Finance, Vinnytsia Finance and Economics University, Ukraine. (Email: andrijsahno@gmail.com)

Iryna Salkova is $\mathrm{PhD}$ in Economics, Associate Professor, Dean of the Faculty of Economics and Entrepreneurship, Vinnytsia National Agricultural University, Ukraine. (Email: irynasalkova@gmail.com)

Antonina Broyaka is an Associate Professor of the Economics Department of Vinnytsia National Agricultural University, Ukraine. (Email: broyaka@yahoo.com)

Priamukhina Nataliia Dr. Sc. (Economics), Associate Professor, Professor of the Economics Department, Vinnitsa National Agrarian University, Ukraine. (Email: 877muha@gmail.com) information and communication technologies in all spheres of life, focus the economy on the spheres of intellectual and creative services: programming, engineering, industrial design, robotics, electronics design. Meanwhile, the next industrial revolution will radically change the world again. We note that nowadays considerable potential of Ukraine is lost and world technological markets have already occupied. The agricultural sector, which is the main national budget-forming industry, remains a prospective direction for the development of the state's economy.

For two consecutive years, the world economic forum in davos was dedicated to this very issue, and the recent forecast for the development of the world until 2035 from the us national intelligence council is thoroughly permeated with the theme of innovation and digitalization [10].

\section{RELATED WORK}

Digitization in the agro-industrial sector is a very relevant topic that has received considerable attention and applied various approaches in the literature. A study by Bowen R. and Morris W. shows that rural areas remain at a disadvantage due to poor digitalization, resulting in brain drain of skilled professionals who move to urban areas. In a developed country like England, the results of a survey of farmers highlight the problems of technology adoption, since $19 \%$ of farmers in the survey do not even have access to the Internet and consequently agribusinesses have got poor opportunities for growth. [1].

Kundius V., Rushchitskaya O., Kot E. devote their scientific works to priority directions of scientific research of engineering and technologies in agriculture, organization and management of agribusiness based on digitization. The authors pay considerable attention to the development of organic agriculture and the functioning of the food market for agricultural organic products. They prove that the digital economy contributes to the development of an innovative information space. Industrial relations undergo change and progressive variation in the structure of the country take place under the influence of the digital economy [2].

Some authors consider human capital in the digital economy and its development as a key factor in ensuring national agricultural security [3], [7]. A number of authors [4], [5], [6], [8] consider digitalization as a means of increasing and ensuring the competitiveness of enterprises, including agricultural ones. 


\section{RESULT AND DISCUSSION}

The significance of the digital economy should be seen in the context of specific sectors of the national economy. Agriculture is the most influential branch in the economic structure of the state, since it provides not only the needs of the domestic consumer, but also promotes effective export policy. Therefore, an assessment of the role of the digital economy should be carried out according to the data on the types of economic activity (KVED - 2005) in agriculture (types of economic activity 1-13, Table-I), which is systematized according to the information resources of the website of the State Statistics Service of Ukraine
The most optimal representation of the development of the digital economy in Ukraine is the level of computer technology introduction, in particular: the production of electronic components and boards, computers and peripheral equipment, communication facilities, electronic household appliances for receiving, recording and reproducing sound and images, instruments and equipment for measuring, researching and navigating, watches, radiological, electro-medical and electro-therapeutic equipment, optical instruments and photographic equipment, magnetic and optical data carriers (types of economic activity 14-21) (Table-I)

Table- I : Indicators of economic activity of enterprises of agriculture, forestry, fisheries, production of computers, electronic and optical products by types of economic activity in 2017

\begin{tabular}{|l|l|l|l|l|}
\hline No & Types of economic activity & $\begin{array}{l}\text { Personnel } \\
\text { costs, mln } \\
\text { UAH } \\
\text { (L) }\end{array}$ & $\begin{array}{l}\text { Value added at } \\
\text { the } \begin{array}{c}\text { aost } \\
\text { of } \\
\text { production, mln } \\
\text { UAH (K) }\end{array}\end{array}$ & $\begin{array}{l}\text { Volume } \\
\text { sales } \text { of } \\
\text { services), mln } \\
\text { UAH (Y) }\end{array}$ \\
\hline 1 & Cultivation of annual and biennial crops & 29151,9 & 362582,4 & 152803 \\
\hline 2 & Plants reproduction & 87,6 & 322 & 220,5 \\
\hline 3 & Animal husbandry & 5015,9 & 52892,2 & 22232,9 \\
\hline 4 & Cultivation of perennial crops & 844,8 & 6226,7 & 3895,9 \\
\hline 5 & Mixed farming & 254,7 & 2645,4 & 1429,1 \\
\hline 6 & Supporting and after harvesting activities in agriculture & 1065,7 & 12701,1 & 5732,1 \\
\hline 7 & Hunting, catching animals and providing related services & 89 & 67 & 45,6 \\
\hline 8 & Forestry and other forestry activities & 1472,1 & 3307,1 & 1870,1 \\
\hline 9 & Logging & 5202,8 & 11608,5 & 6272,3 \\
\hline 10 & Harvesting wild-growing non-timber products & 4,5 & 197,6 & 115,7 \\
\hline 11 & Provision of support services in forestry & 380,9 & 775 & 479,1 \\
\hline 12 & Fishing & 101,9 & 686,5 & 228,4 \\
\hline 13 & Fishery (aquaculture) & 127,5 & 368,6 & 123,1 \\
\hline 14 & Manufacture of electronic components and boards & 249,9 & 1065,1 & 635,4 \\
\hline 15 & Manufacture of computers and peripheral equipment & 281,2 & 2828,5 & 1428,1 \\
\hline 16 & Manufacture of communication equipment & 744,3 & 2532 & 1594,9 \\
\hline 17 & $\begin{array}{l}\text { Production of electronic household appliances for receiving, } \\
\text { recording and reproducing sound and images }\end{array}$ & - & & \\
\hline 18 & $\begin{array}{l}\text { Production of instruments and equipment for measuring, } \\
\text { research and navigation; watch manufacturing }\end{array}$ & 2047,2 & 7181,8 & - \\
\hline 19 & $\begin{array}{l}\text { Production of radiological, electro-medical and } \\
\text { electro-therapeutic equipment }\end{array}$ & 92,9 & 566,3 & 3526,6 \\
\hline 20 & $\begin{array}{l}\text { Manufacture of optical instruments and photographic } \\
\text { equipment }\end{array}$ & 265,8 & 803 & 213,7 \\
\hline 21 & Manufacture of magnetic and optical data carriers & - & - & 403,3 \\
\hline
\end{tabular}

The M. J. Farrell's method of analyzing the functioning environment was chosen to assess the impact of the digital economy on agriculture. For this purpose, two factor indicators were used - personnel costs (L), value added for production costs $(\mathrm{K})$, as well as the resultant indicator - the volume of sales (goods, services) (Y) based on the website data of the State Statistics Service of Ukraine.

Using the data in Table-I, the coefficients of coverage of the volume of sales (goods, services) of personnel costs (L / $\mathrm{Y})$ and value added at production costs $(\mathrm{K} / \mathrm{Y})$ were calculated (Table-II). The statistics on the website of the State Statistics Service of Ukraine do not contain data on the production of household electronic equipment for the reception, recording and reproduction of sound and images (item 17) and magnetic and optical data carriers (item 21). Accordingly, these types of economic activities will not be considered in further calculations.
As a result of calculating the coefficient of coverage of personnel costs with the volume of sold products (goods, services), it was found that in two cases it exceeds «1»: hunting, catching animals and the provision of related services $(1,952)$, and fishery (aquaculture) $(1,036)$. Thus, for these two types of activities, personnel costs exceed the volume of sales (goods, services).

The highest coefficient of coverage of the volume of sales (goods, services) of value added at the cost of production is fishing $(3,005)$, and the lowest is the reproduction of plants $(1,460)$. Thus, it can be concluded that types of economic activities for the production of computers, electronic and optical products should be considered as having an impact on 
economic activity in agriculture, within the framework of which the development of the digital economy is studied (Fig. 1).

Based on the method of analysis of the functioning environment, the line of technical efficiency is a line consisting of items 10 (Harvesting of wild-growing non-timber products), 4 (Cultivation of perennial crops), 2 (Plants reproduction), 7 (Hunting, catching animals and providing related services). Accordingly, the positions of the mentioned types of economic activity are technically effective because of the need to minimize personnel and production costs, based on which the technical inefficiency of other types of economic activities is compared.

Table-II : The Coefficients for covering the volume of sales (goods, services) of personnel costs and value added of production costs by type of economic activity

\begin{tabular}{|c|c|c|c|}
\hline No & Types of economic activity & $\mathbf{L} / \mathbf{Y}$ & $\mathbf{K} / \mathbf{Y}$ \\
\hline 1 & $\begin{array}{l}\text { Cultivation of annual and } \\
\text { biennial crops }\end{array}$ & 0,191 & 2,373 \\
\hline 2 & Plants reproduction & 0,397 & 1,460 \\
\hline 3 & Animal husbandry & 0,226 & 2,379 \\
\hline 4 & Cultivation of perennial crops & 0,217 & 1,598 \\
\hline 5 & Mixed farming & 0,178 & 1,851 \\
\hline 6 & $\begin{array}{ll}\text { Supporting } & \text { and after } \\
\text { harvesting } & \text { activities in } \\
\text { agriculture } & \end{array}$ & 0,186 & 2,216 \\
\hline 7 & $\begin{array}{l}\text { Hunting, catching animals } \\
\text { and providing related services }\end{array}$ & 1,952 & 1,469 \\
\hline 8 & $\begin{array}{l}\text { Forestry and other forestry } \\
\text { activities }\end{array}$ & 0,787 & 1,768 \\
\hline 9 & Logging & 0,829 & 1,851 \\
\hline 10 & $\begin{array}{l}\text { Harvesting wild-growing } \\
\text { non-timber products }\end{array}$ & 0,039 & 1,708 \\
\hline 11 & $\begin{array}{l}\text { Provision of support services } \\
\text { in forestry }\end{array}$ & 0,795 & 1,618 \\
\hline 12 & Fishing & 0,446 & 3,005 \\
\hline 13 & Fishery (aquaculture) & 1,036 & 2,994 \\
\hline 14 & $\begin{array}{l}\text { Manufacture of electronic } \\
\text { components and boards }\end{array}$ & 0,393 & 1,676 \\
\hline 15 & $\begin{array}{l}\text { Manufacture of computers } \\
\text { and peripheral equipment }\end{array}$ & 0,197 & 1,981 \\
\hline 16 & $\begin{array}{l}\text { Manufacture of } \\
\text { communication equipment }\end{array}$ & 0,467 & 1,587 \\
\hline 17 & $\begin{array}{lcr}\text { Production } & \text { of electronic } \\
\text { household } & \text { appliances } & \text { for } \\
\text { receiving, } & \text { recording } & \text { and } \\
\text { reproducing } & \text { sound } & \text { and } \\
\text { images } & & \\
\end{array}$ & - & - \\
\hline 18 & $\begin{array}{l}\text { Production of instruments and } \\
\text { equipment for measuring, } \\
\text { research and navigation; } \\
\text { watch manufacturing }\end{array}$ & 0,580 & 2,036 \\
\hline 19 & $\begin{array}{l}\text { Production of radiological, } \\
\text { electro-medical } \\
\text { electro-therapeutic equipment }\end{array}$ & 0,435 & 2,650 \\
\hline 20 & $\begin{array}{l}\text { Manufacture of optical } \\
\text { instruments and photographic } \\
\text { equipment }\end{array}$ & 0,659 & 1,991 \\
\hline 21 & $\begin{array}{l}\text { Manufacture of magnetic and } \\
\text { optical data carriers }\end{array}$ & - & - \\
\hline
\end{tabular}

The line consisting of items 10 (Harvesting of wild non-timber products), 1 (Growing annual and biennial crops), 12 (Fishing), 13 (Fishery (aquaculture)), 7 (Hunting, catching animals and related services) indicates the availability of technical efficiency based on the need to maximize the volume of sales (goods, services). Items 10 (Harvesting of wild-growing non-timber products) and 7 (Hunting, catching animals and related services) are common to both marginal lines of technical efficiency.

The positions of the types of economic activities for the manufacture of computers, electronic and optical products are not components of any line of efficiency. Therefore, within the conditional polygon 10-1-12-13-7-2 it is possible to construct another polygon 16-14-15-19-18-21 that characterizes the location of the position by type of economic activity for the manufacture of computers, electronic and optical products.

The main feature of both figures is that within the polygon 16-14-15-19-18-21 there is no position of technically inefficient type of economic activity in relation to agriculture, forestry and fisheries. Two conclusions can be drawn from this: first, as of 2017, the development of the digital economy was going beyond production processes in agriculture, forestry and fisheries; secondly, when measuring technical inefficiency, only one connection (0-12) is defined to pass through the area of the polygon. Since the intersection point is close to positions 19 and 15 , it can be assumed that fisheries are ensured by modern advances in the digital economy - radiological equipment and computer systems.

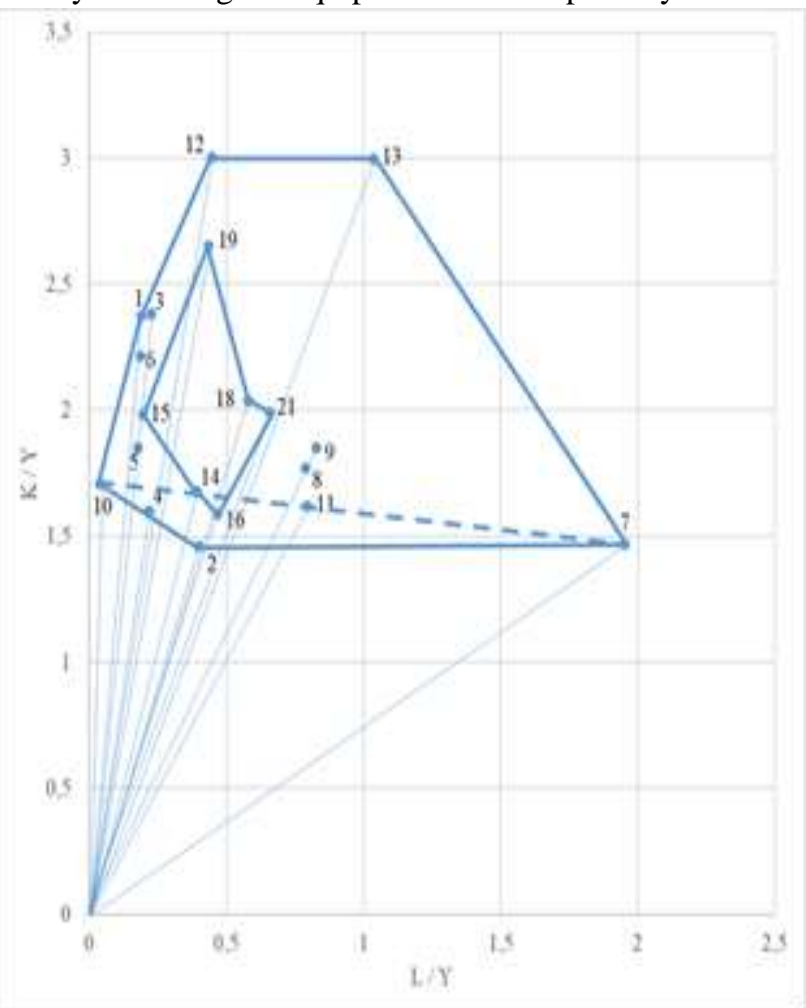

Fig. 1. Positions of types of economic activity according to the results of $\mathbf{2 0 1 7}$ for enterprises in agriculture, forestry and fisheries and the manufacture of computers, electronic and optical products 
Modeling of the digital economy development in the context of the state of the types of economic activity in agriculture (Fig. 2) was carried out minding the need to form new lines of efficiency from the standpoint of the manufacture of computer, electronic and optical products. Therefore, positions 14-1, 16-1, 18-1, 19-1, 21-1 are new positions in such economic activities as the manufacture of electronic components and boards, the production of communication equipment, the production of instruments and measuring equipment, research and navigation, production of watches, production of radiological, electro-medical and electrotherapeutic equipment, manufacture of magnetic and optical data carriers.

Location of the new positions of economic activities by items $14,15,16,18,19,21$ was implemented by designing the lines and points of the corresponding polygon, taking into account the lines of technical efficiency according to the results of the 2017 survey. As a result, the new line of technical efficiency, through cost minimization is as follows: (19-1) - (14-1) - (16-1) - (18-1); through maximizing the volume of sales (goods, services): (19-1) - (21-1) - (18-1).

Thus, new boundaries of technical efficiency for economic activities in agriculture, forestry and fisheries were identified by positioning economic activities in the manufacture of computers, electronic and optical products. As a result, specific indicators of agricultural production can be calculated, which upon achieving technical efficiency, they the volume of sales (goods, services).

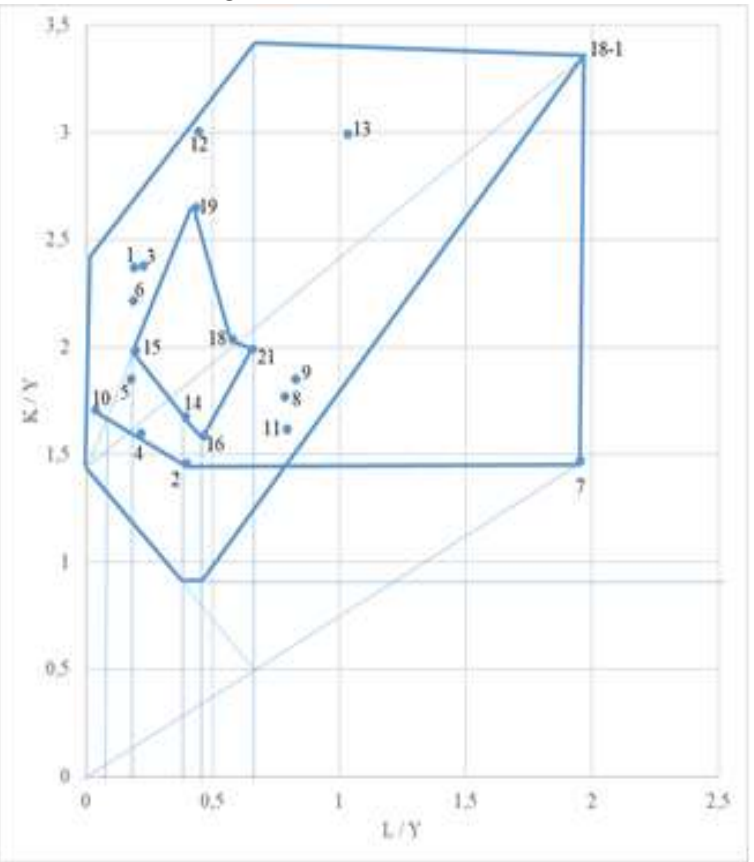

Fig. 2. Modeling of the digital economy development in the context of the state of agricultural economic activities

\section{CONCLUSION}

The conducted research revealed the low level of introduction and activation of the digital economy in agriculture, forestry and fisheries of Ukraine. Using the modern analysis techniques to assess the digital development of the functioning environment has helped to identify the backlog and evaluate the prospects for development of agricultural activities, which can be adjusted through a will be obtained in case of cost reduction and / or increase in

fundamental restructuring of the economy by developing the manufacture of computer, electronic and optical production.

While designing new positions, there are two features were detected, that are subsequently subject to additional elaboration. First, position 7 (Hunting, catching animals and providing related services) is not an inefficient type of economic activity in the new model. Secondly, the intersection of the lines emerging from positions 19-1 and 21-1 forms a new position, which is not separately indicated (in Fig. 2) but requires further research as a potential newest vector of effective development.

The above features provides the actuality for further adjusting the line of technical efficiency by using the method of analyzing the functioning environment for the development of digital technologies in agriculture, forestry and fisheries.

\section{REFERENCES}

1. Bowen, R. \& Morris, W. (2019). The digital divide: Implications for agribusiness and entrepreneurship. Lessons from Wales. Journal of Rural Studies. [Online] Available:

https://www.sciencedirect.com/science/article/abs/pii/S0 743016718312105

2. Kundius, V., Rushchitskaya, O. A., Rushchitskaya, O. E., \& Kot, E. (2019). Development prospects of agrarian science and education in the formation of digital economy. In International Scientific and Practical Conference "Digital agriculture-development strategy" (ISPC 2019). Atlantis Press. [Online]. Available: https://www.atlantis-press.com/proceedings/ispc-19/1259 $\underline{09498}$

3. Kuznetsova, I. G., Voronkova, O. Y., Bakhvalov, S. Y., Ruiga, I. R., Zhuruli, G. N., \& Levichev, V. E. (2018). Formation of Human Capital as a Key Factor in Ensuring the National Security of Agriculture in the Digital Economy. European Research Studies, 21, 73-83.

4. Fedchenko, A. A., Kolesnikova, O. A., Dashkova, E. S., \& Pozhidaeva, T. A. (2019, April). Economic Analysis of Human Resources in the Digital Economy. Institute of Scientific Communications Conference Springer, Cham, 2019. p. 599-605.

5. Tsober, I.Y. (2009) Analysis of approaches to enterprises' competitiveness estimation Actual Problems of Economics,6, 151-155.

6. Ulko, Y., Kucher, A., Salkova, I., Priamukhina, N. (2019) Management of soil fertility based on improvement methodological approach to evaluation of arable land: Case of Ukraine. Journal of Environmental Management and Tourism, 9(7), 1559-1569.

7. Viriyasitavat, W., Da Xu, L., Bi, Z., \& Pungpapong, V. (2019). Blockchain and Internet of Things for Modern Business Process in Digital Economy-the State of the Art. IEEE Transactions on Computational Social Systems. [Online]. Available: https://ieeexplore.ieee.org/abstract/document/8744245

8. Pantielieieva, N., Krynytsia, S., Zhezherun, Y., Rebryk, M., \& Potapenko, L. (2018). Digitization of the economy of Ukraine: Strategic challenges and implementation technologies. In 2018 IEEE 9th International Conference on Dependable Systems, Services and Technologies (DESSERT). 508-515.

9. Events (2019). World Economic Forum [Online]. Available: https://www.weforum.org/focus/davos-2019 
10. Ulezko, A., Reimer, V., \& Ulezko, O. (2019). Theoretical and methodological aspects of digitalization in agriculture. In IOP Conference Series: Earth and Environmental Science. [Online]. Available: https://iopscience.iop.org/article/10.1088/1755-1315/274/ $1 / 012062 / \mathrm{pdf}$

11. Heldak, M., Kucher, A., Stacherzak, A., \& Kucher, L. (2019). Structural transformations in agriculture in Poland and Ukraine: towards economic sustainability. Journal of Environmental Management and Tourism,9(8), 1827-1841.

12. Deichmann, U., Goyal, A., \& Mishra, D. (2016). Will digital technologies transform agriculture in developing countries?. The World Bank. [Online]. Available: https://elibrary.worldbank.org/doi/abs/10.1596/1813-945 $\underline{0-7669}$

AUTHORS PROFILE

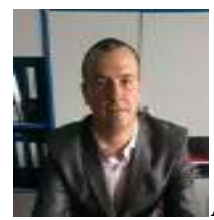

Andrii Sakhno is a Doctor of Economic Sciences, Professor, Head of the Department of Finance, Vinnytsia Finance and Economics University, Ukraine. He defended his thesis on the topic "Motivation of the economic activity of machine-building enterprises: theory, methodology and practice" and received a doctorate on specialty "Economics and management of enterprises (by type of economic activity)" in 2018. A circle of his scientific interests is the development of innovative processes in ensuring the economic activity of business entities in the hypercompetition system.

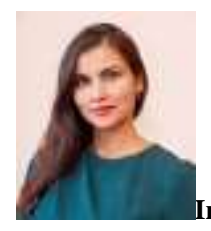
of Economics and Entrepreneurship, an Associate Professor of the Economics Department of Vinnytsia National Agricultural University, Ukraine. She received her $\mathrm{PhD}$ on the field of study "Economics and management of enterprises". Her research interests include economic development of the national economy, management of enterprises competitiveness, investment and innovative development of agro-industrial complex under the conditions of integration processes.

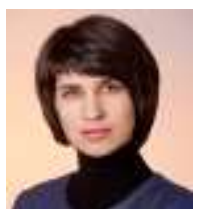

Antonina Broyaka is an Associate Professor of the Economics Department of Vinnytsia Nationa Agricultural University, Ukraine. She received her PhD on the field of study "Economics and management of national economy". Her research interests include microeconomic and macroeconomic processes and problems, strategic management of national economy, economics of agriculture, information and advisory activity in agriculture.

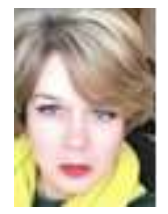

Priamukhina Nataliia is a Doctor of Economic Sciences, Associate Professor, Professor of the Economics Department, Vinnitsa National Agrarian University, Ukraine. Her research interests are the transformation of economic systems, the application of the theory of bifurcations of economic systems, chaos theory, fractal economics, quantum economics. 